\title{
Geneza trudności związanych ze rozumieniem immanencji Boga. Specyfika vjęcia zagadnienia przez Xaviera Zubiriego
}

\section{Niektóre problemy związane z immanencją Boga i ich geneza}

Trudności związane ze zrozumieniem obecności Boga w świecie są domeną czasów przede wszystkim nowożytnych. Zagadnienie nieobecności Boga czy też niedostrzegania Jego obecności w świecie jest wieloaspektowe. Już samo źródło trudności dotyczących dostrzeżenia czy zrozumienia, jak Bóg może być immanentny, nie ma jednolitego charakteru. Trudności te wynikają zasadniczo z tego, że nie mamy bezpośredniego doświadczenia obecności Boga. Ponadto posługujemy się kategoriami nam znanymi, zaczerpniętymi ze świata stworzeń i myślimy o Bogu w ramach tych właśnie kategorii. Przykład tego, jak rodzaj poznania wpływa na rozumienie immanencji Boga, widać w myśli Tomasza z Akwinu oraz Jana od Krzyża, gdzie pojmowanie przejawów obecności Boga naszymi kategoriami poznawczymi może tworzyć trudności w dostrzeżeniu immanencji transcendentnego Boga. Na tle tych dwóch dróg myślenia w sposób szczególny uwidacznia się oryginalność myśli Xaviera Zubiriego. Zubiri, idąc własną drogą włącza w nią inne czynniki, które mają decydujący wpływ na to, czy świat będzie odbierany jako przepełniony Bogiem czy też pozbawiony Go. Tymi czynnikami są osobiste zaangażowanie w stosunku do przyjętej idei Boga oraz zaplecze, jakie stwarza osobista historia życiowa wraz z czasami, w których się żyje. 


\section{Tomasz z Akwinu}

Wizja Tomasza z Akwinu stanowi przykład koncepcji Boga, w której dokonuje się próba ukazania, jak Bóg obecny jest w świecie. Tomasz odsyła do innego rodzaju poznania niż to, którym posługujemy się na co dzień.

Tomasz rozróżnia mówienie o Bogu secundum rem oraz secundum rationem tantum, gdzie pierwszy rodzaj wypowiedzi dotyczy poznania rzeczy w sobie, czyli Boga w Jego istocie, tak jak siebie widziałby Bóg. Drugie to poznanie zgodne $\mathrm{z}$ naturą naszego rozumu, a więc poznanie w ramach pojęć, którymi operuje ludzki umysł¹.

Secundum rem Bóg nie ma części - jest prosty. Jednak secundum rationem tantum wyróżniamy w Bogu złożoność (istota - istnienie, intelekt wola, poszczególne doskonałości itp.). Boża prostota secundum rem oznacza, że Bóg jest wszechobecny i to całym sobą w każdym miejscu świata. Jest tak, gdyż w Bogu nie ma części. Stąd, jeśli działa w jakimś miejscu, to jest tam On cały ${ }^{2}$. Natomiast secundum rationem tantum wszechobecność w przestrzeni i brak części wykluczają się. Dlatego też na tym poziomie poznania nie jesteśmy w stanie pogodzić obecności Boga w każdym bycie stworzonym przy jednoczesnym braku części w Bogu.

Dlaczego poznanie secundum rationem tantum stwarza to napięcie? Powodem jest brak pojęcia, które by ukazywało Boga bez części. My jedynie prostotę Boga opisujemy. Poszczególne składowe pojęcia prostoty Boga są nam znane i jesteśmy w stanie je sobie wyobrazić i pojąć je, ale sposób realizacji tak rozumianej prostoty Boga jest dla nas niepojęty, bo całkowicie niepodobny do świata. Nie wiemy, jak realizuje się w Nim prostota. Tomasz mówi, że wiemy, jaki jest Bóg (tu: prosty), ale nie wiemy, jak to się w Nim realizuje $\mathrm{e}^{3}$.

Podobnie jest z Boską wiecznością. Secundum rem Boska wieczność oznacza, że Bóg jest poza czasem, bo jest niezmienny, a zarazem jest obecny w każdym momencie historii równocześnie ${ }^{4}$. Secundum rationem tantum jesteśmy w stanie sobie wyobrazić czy też pojąć, jak Bóg może być obecny w teraźniejszości, ale nie mamy pojęcia bytu, który jest aktualny w stosunku do każdego momentu historii i sam jest przy tym poza wszelką zmianą. Pojmowalne są dla nas poszczególne treści wchodzące w skład pojęcia wieczności Boga, ale pojęcia wieczności, łączącego w sobie naszą czasowość i pozaczasowość nie mamy. Wieczność jest dla nas niepojmowalna. To prowadzi do wniosku, że w schemacie Tomasza

1 Thomae Aquinatis, Summa theologiae, La Editorial Catolica, S.A. Matriti MCMLXIII, I, 13q, 7a; cfr.: I, 13q, 1-2a. (dalej jako $S$. Th.),

2 S. Th., I, 8q, 1a. I, 8q, 2-4a.

3 S. Th., I, 3q, intro., cfr.: I, 3q, 3a, ad1.

4 S. Th., I, 10q, 1 a. 
z Akwinu na poziomie wypowiedzi secundum rem Bóg może być zarówno transcendentny, jak i immanentny.

Skąd wiemy, jaki ma być Bóg secundum rem? Człowiek wprost nie poznaje ani wieczności Boga, ani Jego prostoty. Wie jedynie nie wprost, w ramach schematu myślenia Tomasza opartego na pięciu drogach, że Bóg w sobie musi być prosty i wieczny, gdyż inaczej świat będzie niezrozumiały. To brak możności na poziomie bytu Boga prowadzi w konsekwencji do koncepcji Boga prostego i wiecznego ${ }^{5}$. Podobnie bycie pierwszą przyczyna, której istotą jest istnienie, oznacza obecność w każdym istniejącym bycie w każdym momencie ${ }^{6}$.

Kiedy powstaje opozycja między transcendencją i immanencją Boga odnośnie do wieczności i prostoty? Gdy wyjaśniamy je przy pomocy pojęć, którymi dysponuje nasz umysł. Stąd wydaje się, że wieczność i prostota zawierają w sobie takie cechy Boga, które się wykluczają. Innymi słowy: wiemy, że w schemacie pięciu dróg Tomasza Bóg musi być wieczny oraz prosty, ale gdy próbujemy to wyjaśnić przy pomocy dostępnych nam pojęć, które odwzorowują świat stworzony (co jest ważne), rodzi się trudność z ich pojęciem. Podsumowując, możemy powiedzieć, że obecność transcendentnego Boga w świecie jest możliwa do wyjaśnienia przy wypracowaniu takiej koncepcji Boga, w której Bóg posiada inną naturę aniżeli świat.

Jeśli jednak pozostaniemy przy myśleniu o Bogu jedynie na poziomie dostępnych nam kategorii, rezygnując z przyznania Mu zasadniczo innej natury, to rodzą się trudności z Boską jednoczesną obecnością w każdym momencie czasu i wszechobecnością. Tak jest w przypadku procesualnej wizji Boga Charlesa Hartshorne'a, w której Bóg musi być czasowy, a w konsekwencji nieobecny w przyszłości

\section{Jan od Krzyża}

Święty Jan od Krzyża opisuje na płaszczyźnie religijnej dynamikę doświadczania immanencji i transcendencji Boga przez człowieka wierzącego, który stara się zjednoczyć z Bogiem. Istotne w tym poznaniu jest kształtowanie się obrazu Boga w człowieku w zależności od intensywności przybliżania się Boga do człowieka. Innymi słowy: stopień bliskości Boga wpływa na sposób doświadczania Jego transcendencji i immanencji ${ }^{8}$.

5 Konsekwencja wynikająca z pierwszej drogi Tomasz z Akwinu.

${ }^{6}$ Konsekwencja wynikająca z drugiej i trzeciej drogi Tomasza z Akwinu.

7 Ch. Hartshorne, The Divine Relativity. A Social Conception of God, Yale University Press New Haven and London 1948, s.121

8 G. Castro, Noche oscura del alma, w: Diccionario de San Juan de la Cruz, (red.) E. Pacho, Monte Carmelo Burugos 2000, s. 1052-1054. 
Obiektywną obecnością Boga nazwijmy rzeczywiste oddziaływania Boga na ludzkie władze poznawcze. Subiektywną obecnością Boga nazwijmy subiektywny doświadczany przez człowieka obraz Boga w momencie, gdy Bóg się obiektywnie do człowieka przybliża.

Święty Jan od Krzyża w swojej teorii mistycznego poznania Boga opisuje sytuację graniczna, jaką jest przejście od pośredniego do bezpośredniego poznania Boga. W swojej teorii stara się wyjaśnić, w jaki sposób dokonuje się to przejście u osób, które oddają się kontemplacji Boga i osiągnęły stan finalny zwany zjednoczeniem z Bogiem, w którym poznanie Boga jest bezpośrednie.

Jan od Krzyża wyjaśnia, że w życiu duchowym nadchodzi taka chwila, gdy Bóg sam ze swojej strony zaczyna bezpośrednio oddziaływać na ludzkie władze poznawcze, w celu przybliżenia człowieka do siebie 9 . Jest to moment, gdy obiektywnie Bóg jest blisko człowieka, w sensie intensywniejszego oddziaływania na jego władze duchowe. Paradoksalnie subiektywnie człowiek doświadcza wówczas Boga, jako tego, który się ukry110, jako odległego, nieakceptującego człowieka, wymagającego. Wyrażając to $\mathrm{w}$ innych słowach, można by powiedzieć, że obiektywna bliskość Boga rodzi w człowieku subiektywne doświadczenie Jego oddalenia.

Co jest powodem takiego subiektywnego obrazu Boga? Jan od Krzyża wyjaśniając to zagadnienie, powołuje się na Arystotelesa i podaje przykład nietoperza oślepionego światłem słońca. Człowiek widzi w świetle słonecznym, gdyż jego wzrok jest do tego przystosowany. Inaczej jest $\mathrm{z}$ nietoperzem. To niedostosowanie wzroku nietoperza do światła słonecznego powoduje, że gdy zdawać by się mogło, że warunki do oglądania świata są najlepsze - ten nic nie widzi. Podobnie jest z człowiekiem. Gdy obiektywnie Bóg jest blisko człowieka, ten odczuwa tę bliskość jako oddalenie się Boga. Sięgając głębiej, powodem „niewidzenia” Boga w momencie Jego bliskości jest nieprzystosowanie człowieka do bezpośredniego doświadczenia Boga ${ }^{11}$.

Na czym polega to nieprzystosowanie? W normalnych okolicznościach człowiek poznaje Boga pośrednio. To znaczy przy pomocy pojęć, które odnoszą się bardziej do świata niż do Boga. Z pewnością pojęcia te mają charakter mocno antropomorficzny. W czasie kontemplacji następuje zmiana sposobu poznania Boga. Bóg przejmuje inicjatywę i sam zaczyna być przedmiotem poznania - wypierając ludzkie pojęcia, daje się doświadczyć człowiekowi bezpośrednio. Będąc bytem o innej natu-

9 Jan od Krzyża, Noc ciemna, w: Dzieła, tłum. B. Smyrak, Wydawnictwo Karmelitów Bosych, Kraków 1986, 2,5,1.

10 Ibidem, 2,17,2.

11 Jan od Krzyża, Droga na Górę Karmel, w: Dzieła, tłum. B. Smyrak, Wydawnictwo Karmelitów Bosych, Kraków 1986, I,3,3; II,11,70; II,8,6. 
rze niż świat, nie jest podobny do pojęć, którymi człowiek posługiwał się do tej pory. Ponieważ istnieje radykalna różnica między pojęciami odnoszącymi się do Boga a samym Bogiem, Ten, gdy jest bezpośrednio doświadczany, stanowi dla człowieka nową i nieznaną rzeczywistość, radykalnie inna, niż ta, którą znał do tej pory, utożsamiając ją z Bogiem. Dawny obraz Boga, jaki posiadał człowiek, był człowiekowi bliski, choć było to tylko poznanie pośrednie ${ }^{12}$. Teraz, gdy Bóg decyduje, aby samemu stać się treścią ludzkiego poznania, dawne pojęcia Boga, którymi człowiek do tej pory się posługiwał, stają się przeszkodą w tym bezpośrednim poznaniu. Człowiek nie jest skory do porzucenia znanego sobie obrazu Boga na rzecz nowego, całkiem dla niego obcego. To skutkuje poczuciem nieobecności Boga, poczuciem Jego oddalenia.

Jednocześnie w trakcie oczyszczenia ustala się w człowieku nowy porządek poznawczy. Jan od Krzyża wspomina o duchu jako o pewnej funkcji duszy ${ }^{13}$. Duch jest w stanie otworzyć się na bezpośrednie poznania Boga. W duchu człowiek poznaje Boga bez pomocy pojęć, to znaczy bez formy czy kształtu. Jest to poznanie z pominięciem wszelkich form pośredniczących. Bóg sam daje się poznać człowiekowi i On staje się formą poznawcza, nie zaś pojęcie ${ }^{14}$. Jest to czas połączony z wielkim cierpieniem w życiu ludzkim, gdyż wiąże się z subiektywnym poczuciem nieobecności Boga, a nawet poczuciem odrzucenia przez Niego ${ }^{15}$.

Jaki jest ostateczny skutek takiego działania Boga? Jan mówi, że gdy ludzkie poznanie zostanie przez Boga przekształcone (oczyszczone), to człowiek nie polega już na poznaniu opartym na pojęciach, ale jest otwarty na bezpośrednie poznanie Boga. Wtedy też znika doświadczenie Boga jako nieobecnego. Bóg jest doświadczany w nowy sposób. Wtedy też człowiek harmonijnie doświadcza Boga jako bytu absolutnie transcendentnego a jednocześnie na wskroś immamentnego. Bóg jest doświadczany jako stale obecny we wnętrzu człowieka, w historii itp. Wcześniejsze napięcie między transcendencją i immanencją zostaje przezwyciężone $\mathrm{w}$ tym sensie, że transcendencja Boga, która jest poznawana jako jeszcze bardziej odróżniająca Boga od świata, nie przeszkadza w doświadczeniu Jego immanencji ${ }^{16}$.

Konkludując, możemy powiedzieć, że powodem subiektywnego odczuwania immanencji Boga jako Jego nieobecności wg Jana od Krzyża jest pojęciowość ludzkiego poznania, w tym jego antropomorfizacja.

12 Por. Idem, Droga..., op. cit., II,14,8.

13 Idem, Żywy Płomień Miłości, w: Dzieła, tłum. B. Smyrak, Wydawnictwo Karmelitów Bosych, Kraków 1986, 3,69.

14 Idem, Droga..., op. cit., 2, 15, 2; PD 14 i 15,12.

15 Idem, Noc ciemna, 2, 5-8.

16 Idem, Żywy płomień..., op. cit., 3, 28; por.: idem, Pieśń Duchowa, w: Dzieła, tłum. B. Smyrak, Wydawnictwo Karmelitów Bosych, Kraków 1986, 24,3. 
W ramach pojęciowego poznania Boga myślimy o Nim w kategoriach, które czerpiemy ze świata ludzi. To one powoduja, że gdy Bóg jest szczególnie blisko człowieka, ten odczytuje tę bliskość jako oddalenie. Aby to przezwyciężyć, potrzebna jest zgoda na zburzenie dawnego myślenia o Bogu i przyjęcie całkiem nowego.

\section{Fenomenologiczno - metafizyczna droga Zubiriego do Boga}

Zubiri dochodzi do odkrycia Boga i Jego obecności w świecie, zaczynając od fenomenologicznej analizy tworzenia ludzkiego Ja. To rzeczywistość stymuluje Ja do tworzenia się. Obierając konkretną formę bycia, człowiek jako osoba opiera się ostatecznie na konkretnym kształcie rzeczy stanowiących rzeczywistość ${ }^{17}$.

Rzeczywistość jest tym, w czym się znajdujemy. Zubiri wymienia trzy cechy rzeczywistości, które stanowią specyficzny fundament ludzkiego Ja. Po pierwsze jest ona czymś ostatecznym (algo último) w moich czynach jako osoby, gdyż daje mi ostateczne oparcie. Po drugie, człowiek w swoich czynach dąży do pewnego celu, to znaczy, aby osiągnąć pewną formę rzeczywistości swojego Ja, wybiera jedną z możliwości, jaką mu ofiarowuje rzeczywistość. Dlatego rzeczywistość ma charakter umożliwiający (posibilante). Po trzecie, rzeczywistość jest także podstawą (apoyo implemente) pociągającą czy też pobudzająca, gdyż pobudza człowieka do wybierania swoich możliwości ${ }^{18}$.

Łącząc w jedno ostateczność, umożliwianie i pobudzanie ze strony rzeczywistości, dochodzimy do pojęcia religacji. Religacja jest kluczowym pojęciem w kwestiach związanych z Bogiem. Oznacza ona przywiązanie mojego Ja do rzeczywistości, o ile ta jest rzeczywistością dającą nową formę bycia mojemu Ja. Ze strony rzeczy Zubiri religację nazywa władzą rzeczywistości. Jest to taka cecha rzeczywistości, która mówi o jej zdolności konstruowania, gdyż rzeczywistość dominuje nad rzeczami, w tym nad moim Ja.

Władza rzeczywistości jest żywa, jest źródłem wszystkich rzeczy i dotyka człowieka osobiście. W ciągu historii człowiek odkrywa wszystkie te trzy wymiary władzy rzeczywistości ${ }^{19}$. Odkrycia te wyrażone pod postacią religii nadają różnym cechom władzy rzeczywistości imiona bóstw.

17 X. Zubiri, El problema filosófico de la historia de las religiones, Alianza Editorial, Fundación Xavier Zubiri Madrid 2006, s. 38.

18 X. Zubiri, El hombre y Dios, Nueva edición, Alianza Editorial, Fundación Xavier Zubiri Madrid 2012, s. 89-91.

19 X. Zubiri, El problema..., op. cit., s. 40-50. 
Działanie religacji leży u podstaw każdego ludzkiego działania, ponieważ w każdym ludzkim działaniu ma miejsce tworzenie ludzkiego Ja. Każdy akt osobowy, choćby najmniejszy, zawsze kształtuje Ja. Człowiek nie ma doświadczenia religacji, ale jest doświadczeniem religacji. Religacja nie jest żadną religią pozytywną. Niemniej bez religacji nie istniałaby żadna religia pozytywna ${ }^{20}$.

Władza rzeczywistości nie jest identyczna z rzeczami. Rzeczy to jedynie wewnętrzne wektory władzy rzeczywistości. Człowiek realizuje się w takiej formie rzeczywistości, do której go rzeczy niejako zmuszają. Życie w rzeczywistości nie jest możliwe bez rzeczy. Niemniej rzeczy jedynie otwierają na władzę rzeczywistości, a ona zmusza człowieka do wyboru $^{21}$.

Władzę rzeczywistości posiadają rzeczy o ile są realne i o ile stanowią część lub moment rzeczywistości. Rzeczywistość to nie tylko jakiś zwykły koncept ani coś odseparowanego od rzeczy. To moment fizyczny rzeczy, który nas determinuje fizycznie. Rzeczywistość nie jest czymś oddzielonym od rzeczy ${ }^{22}$.

Religacja, władza rzeczywistości, jej ostateczność, tworzenie możliwości dla Ja, pobudzanie do wybierania są faktami. Oznacza to, że są dane w bezpośrednim doświadczeniu. Do tego miejsca Zubiri - jak sądzi - działa jako fenomenolog. Następny krok Zubiri umieszcza już w sferze badań metafizycznych, gdyż wykracza poza to, co jest bezpośrednio dane $\mathrm{w}$ doświadczeniu rzeczywistości. Tworzenie ludzkiego Ja w oparciu o religację zawiera pewną tajemnicę, zwaną przez Zubiriego enigma, gdyż nie wiemy, skąd rzeczy mają moc, aby tworzyć ludzkie Ja. Ten tajemniczy wymiar, w którym człowiek jest otwarty na konfrontację z czymś ostatecznym w rzeczywistości, Zubiri nazywa teologalnym. Moment teologalny człowieka jest jego elementem konstytutywnym. Zubiri stwierdza, że jeśli w ludzkiej rzeczywistości odkryjemy jakiś wymiar, który faktycznie konstytutywnie w sposób nieunikniony zawiera konfrontację z tym, co ostateczne w rzeczywistości, to tę ostateczność rzeczywistości nominalnie i prowizorycznie możemy nazwać Bogiem. Nie dysponujemy jakimś konkretnym obrazem Boga. Bóg jest jedynie przestrzenią tego, co ostateczne $\mathrm{w}$ rzeczywistości w powiązaniu $\mathrm{z}$ tworzeniem Ja.

Tam, gdzie rzeczywistość nie tłumaczy się sama, to znaczy zawiera pewną zagadkę, tam domaga się swojego fundamentu ${ }^{23}$. I tak jest w przypadku człowieka i jego Ja. Tym fundamentem ma być Bóg. Bóg

20 Ibidem, s. 52-53.

${ }^{21}$ Idem, El hombre..., op. cit., s. 8.

22 Ibidem, s. 158.

${ }^{23}$ Idem, Inteligencia y razón, Alianza Editorial, Fundación Xavier Zubiri Madrid 2008, s. 83. 
jako fundament nie jest bezpośrednio dany, ale poszukiwany w oparciu o to, co jest dane w bezpośrednim doświadczeniu ludzkiej rzeczywistości. Jeśli dotychczasowe poznanie ludzkiej rzeczywistości nie jest pełne, właśnie ze względu na brak poznania jej fundamentu, to sama rzeczywistość popycha w kierunku jego znalezienia. Istnienie w człowieku sfery teologalnej domaga się właśnie fundamentu ${ }^{24}$. To, co teologalne, to wyłącznie ludzka przestrzeń, która jest bezpośrednio dostępna analizie. Zdanie sobie sprawy z istnienia tej przestrzeni w człowieku jest uświadomieniem sobie problemu istnienia Boga. Zaczynając od tego punktu, możemy próbować odpowiedzieć na pytanie, kim jest Bóg i jak jest obecny w świecie ${ }^{25}$. Niedostrzeżenie tego punktu będzie źródłem zamknięcia się na poznanie obecności Boga w rzeczywistości.

$\mathrm{Z}$ wymiarem teologalnym człowieka i jego enigmatycznością wiąże się zagadnienie Boga także w tym sensie, że każda rzecz jest jedynie jakąś rzeczywistością, a u jej podstaw leży pełna rzeczywistośćc ${ }^{26}$. Ponieważ w tworzeniu Ja jesteśmy całkowicie zdani na rzeczywistość, stąd jesteśmy fizycznie rzuceni w kierunku pełni rzeczywistości przez władzę rzeczywistości, która jest enigmatyczna. Problematyczność naszego Ja polega na tym, że nie wiemy, co jest fundamentem rzeczywistości, która nam umożliwia tworzenie się $e^{27}$.

Tutaj też pojawia się dla nas pierwszy ważny wniosek: rzeczywistość nie stanowi dla nas problemu czysto intelektualnego, gdyż dotyczy tajemnicy tworzenia naszego $\mathrm{Ja}^{28}$. Jest to dla naszych poszukiwań ważne stwierdzenie, gdyż ukazuje, gdzie Zubiri będzie umiejscawiał problemy związane z odkryciem boskiej immanencji w świecie i w ludzkim życiu.

Droga ku fundamentowi rzeczywistości jest wieloznaczna, ponieważ rzeczy są jedynie narzędziem, którym posługuje się władza rzeczywistości. To też wymaga stworzenia pewnego szkicu, który na zasadzie hipotezy będzie fundamentem rzeczywistości. Szkice mogą być różne, jak na przykład: ateizm, teizm, agnostycyzm ${ }^{29}$. Szkic jest czymś koniecznym, gdyż bez szkicu nie będziemy wiedzieli, czego należy szukać i co należy następnie potwierdzić ${ }^{30}$.

Szkic musi nawiązywać do tego, co dane w bezpośrednim doświadczeniu. Jest to tak zwany system referencyjny, którym szkic się inspiruje i względem którego będzie następnie weryfikowany. Fundament jest za-

24 Ibidem, s. 63-64.

25 Idem, El hombre..., op. cit., s. 5-6.

26 Ibidem, s. 102.

27 Ibidem, s. 104.

28 Ibidem, s. 243-244.

29 Ibidem, s. 10.

30 Idem, Inteligencia..., op. cit., s. 220-221. 
leżny od systemu referencyjnego, gdyż system sugeruje, co mogłoby być fundamentem ${ }^{31}$.

Jaki zatem miałby być szkicowany Bóg, aby mógł wyjaśnić enigmę? Powinien być fundamentem władzy rzeczywistości, czyli musi być fundamentem ostatecznym, umożliwiającym i pobudzającym. Jednocześnie będzie on rzeczywistością, która jest fundamentem mojego Ja. Osiągnie się to, gdy szkicowany fundament będzie absolutny w sensie zupełnej niezależności od czegokolwiek. Będzie on absolutny w prosty sposób, absolutnie absolutny, czyli nie ze względu na bycie wobec rzeczywistości, ale sam w sobie jako rzeczywistośćc ${ }^{32}$. Dodatkowo musi to być rzeczywistość osobowa ${ }^{33}$. Zubiri stwierdza, że szkic fundamentu tworzymy w oparciu o całe nasze zaplecze duchowe, intelektualne itp. Dlatego szkice muszą być różne i historycznie są takie właśnie. Stąd istnieje pewna dowolność w tworzeniu szkiców. Niemniej istotną rzeczą jest weryfikacja szkicu.

Aby wypróbować szkic trzeba dokonać doświadczenia (experiencia), które zdoła potwierdzić lub zaprzeczyć słuszność szkicu. Każdy z możliwych szkiców: ateizm, teizm, indyferentyzm oraz agnostycyzm są jednocześnie jakimiś formami doświadczania fundamentu, czyli weryfikowania go. Stąd ateizm, teizm itp. nie są czysto intelektualnym ustosunkowaniem się do fundamentu, ale życiowym próbowaniem ${ }^{34}$. Człowiek zwraca się ku naszkicowanej przez siebie rzeczywistości, szukając w niej oparcia, gdyż przyjęty szkic ma być fundamentem mojego Ja. Umiejscowienie szkicu $\mathrm{w}$ możliwościach realizacji mojej osoby jest próbowaniem, sprawdzaniem szkicowanego fundamentu rzeczywistości. Jest to sprawdzanie obecności ostateczności, możliwości i pobudzania tak naszkicowanych w mojej własnej rzeczywistości ${ }^{35}$.

Doświadczenie, czyli weryfikacja, jest możliwe jedynie, gdy człowiek zaangażuje się w pełni w stosunku do szkicowanego fundamentu. Dopiero wtedy możemy mieć pełen dostęp do fundamentu, aby móc go zweryfikować36 . Aby to się stało, potrzeba mojej akceptacji przechodzącej w zaangażowanie (entrega). Zaangażowanie polega na pozwoleniu, aby tworzenie mojego Ja dokonało się w ten sposób, że powstaje ono w oparciu o szkicowany fundament działającego w rzeczach. Najpełniej dokonuje się to $\mathrm{w}$ religii. Zaangażowanie to tworzenie życia $\mathrm{w}$ funkcji fundamentu działającego $\mathrm{w}$ rzeczywistości czy też przez nią. Istnieje

31 Ibidem, s. 219-220.

32 Idem, El hombre..., op. cit., s. 148-149.

33 Idem, Naturaleza, Historia, Dios. Alianza Editorial, Fundación Xavier Zubiri Madrid 2007, s. 412.

34 Ibidem, s. 12.

35 Idem, s. 100-101.

36 Idem, El hombre..., op. cit., s. 214-215. 
także możliwość odrzucenia zaangażowania się $e^{37}$. Zaangażowanie jest bliskie wierze $(f e)$, ale nie w sensie religijnym. Wiara jest jednym $\mathrm{z}$ takich możliwych stanowisk, tak samo jak powstrzymanie się od zajęcia stanowiska wobec fundamentu jest już jakąś decyzją wobec niego ${ }^{38}$. Zaangażowanie to inny, obok odkrycia tajemnicy i szkicowania, ważny moment odkrywania obecności fundamentu, czyli Boga w świecie. Wiara i ofiarowanie się Bogu jest według Zubiriego warunkiem do dostępu do niego ${ }^{39}$. Brak wiary lub zaangażowania się będzie skutkował nieznalezieniem Boga.

Bóg dla Zubiriego nie jest tym, który zapełnia ludzkie braki i potrzeby, ale tym, który daje mu pełnię bycia (ser) i życia ${ }^{40}$ i dlatego bez zaangażowania się nie ma możliwości odkrycia obecności Boga w rzeczywistości. Z drugiej strony, zaangażowanie się chroni przed spekulacją która nie jest drogą prowadzącą do Boga, a jedynie do jakiejś intelektualnej idei. Wtedy bowiem Bóg jest traktowany jak przedmiot ${ }^{41}$. Zaangażowanie pochodzi od woli prawdy. Wola prawdy popycha inteligencję, aby precyzować, czym jest ów fundament ${ }^{42}$. Elementami zaangażowania są szacunek, poważanie i hołd wobec szkicowanego fundamentu, bo fundament jest kimś ostatecznym. Kolejnym elementem jest prośba, która jest źródłem modlitwy, bo Bóg stwarza możliwości dla mojego Ja. I wreszcie zaangażowanie $\mathrm{w}$ relację z Bogiem jako rzeczywistość pobudzającą przekształca się w uznanie Boga jako bezpieczne miejsce ${ }^{43}$.

Człowiek przyjmuje rzeczywistość-fundament jako swoją gdy pozwala Mu dziać się w sobie, czyniąc Go swoim. Jest to wspomniana wyżej wola prawdy, która staje się wolą fundamentu ${ }^{44}$. Wola prawdy, przekształcając się $\mathrm{w}$ wolę fundamentu, nabiera religijnego charakteru ${ }^{45}$. Wola fundamentu nie jest aktem, ale pewną postawą. Wola fundamentu inicjuje proces mający na celu odkrycie możliwości, które daje rzeczy-

37 Ibidem, s. 248.

38 Ibidem, s. 252.

39 H.C. Gudiel, La fe según Xavier Zubiri. Una aproximación al tema desde la perspectiva del problema teologal del hombre, Editrice Pontificia Universitá Gregoriana Roma 2006, s. 207.

40 A. Pintor-Ramos, Religación y "prueba" de Dios en Zubiri, "Razón y Fe", nov. 1988, s. 331.

41 Ibidem, s. 333.

42 F. Llenín Iglesias, La realidad divina. El problema de Dios en Xavier Zubiri, Seminario Metropolitano Oviedo 1990, s. 115.

43 D. Gracia, El tema de Dios en la filosofia de Zubiri, Estudios Eclesiásticos, vol. 56, 216-217/1981, s. 76.

44 X. Zubiri, El hombre..., op. cit., s. 269.

45 M. Jagłowski, Realizm transcendentalny Xaviera Zubiriego, Wydawnictwo Uniwersytetu Warmińsko-Mazurskiego Olsztyn 2000, s. 247. 
wistość i uznanie ich za swoje, aby tworzyć swoje Ja ${ }^{46}$. Wola prawdy i fundamentu umożliwia mi proces weryfikacji szkicu.

W przypadku, gdy przyjmuje się, że szkicowanym fundamentem jest rzecz, a nie osobowy Bóg (jak to jest w badaniach naukowych) ma miejsce zaangażowanie o charakterze utylitarnym, a nie osobowym. W przypadku fundamentu osobowego (Boga) jest on traktowany przeze mnie w ten sposób, że angażuję się osobowo, to znaczy ze względu na mnie samego ${ }^{47}$. Czasami jednak człowiek woli zamienić osobową rzeczywistość-fundament w rzecz, aby nie zaangażować się osobowo, nie pytać się o osobowy fundament i tym samym oddalić się od Boga ${ }^{48}$. To właśnie wtedy pozostaje się na poziomie rzeczy i Bóg staje się Bogiem-przedmiotem. Wtedy Bóg stanowi uzupełnienie ludzkich braków. Zubiri uważa, że prawdziwego Boga można znaleźć jedynie wtedy, gdy Ten zabezpiecza pełnię ludzkiego bycia i życia, czyli przede wszystkim sferę osobową ${ }^{49}$.

Zubiri wysoko ceni ten typ badania rzeczywistości, który ma miejsce $\mathrm{w}$ zaangażowaniu. Zaangażowanie się nie należy do sfery racjonalnej, ale jest zbieżne $\mathrm{z}$ racjonalnością. Jest to działanie rozumne (razonable). Rozumne w tym wypadku to coś więcej niż racjonalne ${ }^{50}$. Rozumny to znaczy koherentny z rzeczywistościa, czyli prawdziwy ${ }^{51}$. Jest to zgodność tego, co racjonalne z możliwościami mojego własnego życia i mojej własnej rzeczywistości ${ }^{52}$. Rozumność fundamentu nie polega na tym, że ma bezpośrednie potwierdzenie w rzeczach, ale na tym, co fundament zabezpiecza. W tym wypadku fundament zabezpiecza możliwość tworzenia ludzkiego Ja. Podobnie jest w fizyce teoretycznej, biologii, historii. Doświadczenie, czyli sprawdzanie, jest nazwane przez Zubiriego "fizycznym próbowaniem rzeczywistości". To znaczy, że szkicowany fundament przystaje do danych wyjściowych, wyjaśniając ich bogactwo i rozwiązuje enigmę, choć tylko prowizorycznie ${ }^{53}$.

Zubiri w swoich badaniach filozoficznych pozytywnie weryfikuje szkicowany obraz Boga tak, jak jest On nakreślony powyżej, czyli jako absolutnie absolutny, osobowy itp. Taki Bóg jest w stanie zgodnie z systemem referencyjnym danym na początku zagwarantować mój rozwój osobowy w każdej chwili życia, a także po śmierci. Ponadto Zubiri wyjaśnia, skąd rzeczywistość ma tę moc, że może tworzyć moje Ja. Jest to

46 X. Zubiri, El hombre..., op. cit.,s. 271.

47 Ibidem, s. 265-266.

48 Ibidem, s. 473.

49 A. Pintor-Ramos, Dios y el problema de la realidad en Zubiri, "Cuadernos de Pensamiento" 1/1987, s. 115.

${ }^{50}$ X. Zubiri, El hombre..., op. cit., s. 276-277.

51 Idem, El problema..., op. cit., s. 283.

52 Idem, El hombre..., op. cit., s. 434-435.

53 A. Pintor-Ramos, Religación y..., op. cit., s. 330. 
bardzo ważne stwierdzenie, gdyż tylko w tym wypadku jestem usprawiedliwiony przyjąć szkicowany obraz Boga. Nie każdy szkic jest pozytywnie weryfikowany. Ważna jest zgodność szkicu z systemem referencyjnym. Stąd szkice mogą być bardziej lub mniej udane i można je pod tym względem wartościować. Jeśli ateizm, agnostycyzm i indyferentyzm są pewnym szkicami rzeczywistości-fundamentu, to tym samym podlegają one ocenie pod względem zbieżności z systemem referencyjnym.

Wniosek, do jakiego dochodzi Zubiri, jest następujący. Fundament rzeczywistości to osobowy Bóg. Człowiek spotyka Boga, gdy realizuje się $\mathrm{w}$ religacji jako osoba. Boga spotyka się we wszystkich rzeczach, a także w sobie. Rzeczy są realne w Bogu. Enigmatyczna władza rzeczywistości panująca nad człowiekiem to działający przez rzeczy Bóg. W tym zawładnięciu ludzkiego Ja przez rzeczywistość dokonuje się intelekcja Boga. Stąd osobowa realizacja człowieka dokonuje się jako dowolna konfiguracja ludzkiego Ja w odniesieniu do Boga w mojej oso$b_{i e}{ }^{54}$. Ponieważ Bóg jest obecny $w$ rzeczach, stąd każda rzecz jest ambiwalentna, bo z jednej strony jest swoją rzeczywistościa, z drugiej jest ustanowiona w Bogu. Bez Boga w rzeczy ta nie byłaby realna. Ta jedność rzeczy i Boga jest rozwiązaniem enigmy rzeczywistości ${ }^{55}$. Bóg, będąc fundamentem rzeczywistości, jest jednocześnie fundamentem religacji ${ }^{56}$.

\section{Geneza problemów z immanencją Boga według Zubiriego}

Dopiero teraz jesteśmy $\mathrm{w}$ stanie uchwycić, skąd się biorą trudności związane z percepcją Boga w świecie. Trudności te Zubiri zasadniczo ujmuje $\mathrm{w}$ trzech postawach jakimi są: ateizm, obojętność oraz agnostycyzm. Według Zubiriego każda z tych postaw jest pewnym przyjętym szkicem tłumaczącym świat, człowieka i ich fundament i życiem według tego szkicu.

Droga ku fundamentowi jest wieloznaczna, ponieważ rzeczy są jedynie narzędziem, którym posługuje się władza rzeczywistości. Człowiek zawsze ma fizyczny kontakt $\mathrm{z}$ fundamentem. Jednak są różne drogi ku fundamentowi, stąd ateizm, teizm, agnostycyzm. Te drogi to jednocześnie różne sposoby intelektualnego usprawiedliwienia obranej drogi ku fundamentowi ${ }^{57}$.

Należy rozróżnić między doświadczeniem władzy rzeczywistości, które ma charakter rzeczywisty a intelektualnym usprawiedliwieniem

\footnotetext{
54 X. Zubiri, El hombre..., op. cit., s. 10-11.

55 Ibidem, s. 166.

56 Ibidem, s. 195.

57 Ibidem, s. 10.
} 
dokonanych wyborów. Doświadczenie (experiencia) ma charakter badania, próbowania. Jest to doświadczenie fundamentu. W nim dokonuje się intelekcja fundamentu. Ateizm, teizm oraz agnostycyzm są formami doświadczania fundamentu, a to oznacza, że nie są czysto intelektualnym ustosunkowaniem się do fundamentu, tylko próbą życia zgodnie ze szkicowanym fundamentem, aby go potwierdzić. Każde doświadczenie jest zawsze dokonywane $\mathrm{z}$ indywidualnej perspektywy uwarunkowanej momentem historii oraz społeczeństwa, w którym ktoś żyje ${ }^{58}$. Nic więc dziwnego, że dziś ludzie inaczej szkicują i weryfikują fundament niż sto, tysiąc lat temu.

\section{Ateizm}

Każdy człowiek, także ateista doświadcza religacji, a więc wchodzi w kontakt z Bogiem, nawet nie mając tego świadomości ${ }^{59}$. Ateizm utożsamia władzę rzeczywistości z rzeczami i niczym więcej. Jest to czysta faktyczność władzy rzeczywistości. W ateizmie optuje się za samowystarczalnością życia. Jeśli Zubiri uznaje, że rzeczy nie są własnym fundamentem, bo nie wyjaśniają same z siebie, skąd mają w sobie tę moc, że mogą tworzyć ludzkie Ja, to według Zubiriego, ateizm ignoruje ten fakt. Ateizm ignoruje tajemnicę rzeczywistości. Ateizm poprzestaje tylko na samym fakcie, że rzeczywistość umożliwia i przymusza do tworzenia $\mathrm{Ja}^{60}$. W tym wypadu życie jest tym, czym jest i niczym więcej. Nie ma fundamentu, który należy wybierać. Nie jesteśmy rzuceni $\mathrm{w}$ żadnym kierunku ${ }^{61}$.

Człowiek jako rzeczywistość zależna od rzeczywistości pełnej może akcentować różne swoje momenty. Jeśli przeakcentuje moment swojej niezależności, wówczas dochodzi do ateizmu. Dopiero akcentując element własnej zależności od rzeczywistości, afirmuje się Boga jak rzeczywistość absolutną. $W$ ateizmie tak nie jest ${ }^{62}$. W ateizmie człowiek za bardzo się koncentruje na własnych sukcesach, przeceniając własne siły. To dywinizacja samego siebie ${ }^{63}$.

Ateizm jest pewnym szkicem, który weryfikuje się przez zaangażowanie się. Każdy szkic musi być bowiem weryfikowany. W praktyce oznacza to życie w taki sposób, jakby rzeczywistość była sama dla

58 Ibidem, s. 12.

59 M. Jagłowski, s. 230.

60 Ibidem, s. 294-298.

61 M.D. González, Dios, problema de todos, w: (red.) Seminario Zubiri-Ellacuría, Voluntad de vida. Ensayos filosóficos, Dirección de Cultura UCA / Departamento de Filosofía e Historia UCA Managua 1993, s. 85.

62 D. Gracia, s. 75.

63 F. Llenín Iglesias, s. 32. 
siebie fundamentem i nie potrzebowała swojej podstawy. Weryfikacja tego typu jest swoiście rozumianą wiara, w której człowiek zawierza się rzeczywistości jako takiej. Jest to wiara ateisty. Innymi słowy ateizm to sposób życia, w którym wola fundamentu spoczywa na Ja, jako czymś absolutnym na swój sposób ${ }^{64}$.

Ateistyczny szkic nie odpowiada jednak na pytanie, jak tak rozumiana rzeczywistość może mi zagwarantować trwałość życia po śmierci oraz skąd ma ona moc do tworzenia Ja. Innymi słowy, taki szkic fundamentu nie pozwala rozwijać się Ja w pełni. Jest więc mało satysfakcjonujący.

\section{Indyferentyzm}

Innym szkicem fundamentu jest indyferentyzm. W tym szkicu człowiek zadawala się samym życiem. Jest to, według Zubiriego, frywolność. Ta postawa nie jest do utrzymania, gdyż religacja jest bezsporna. Człowiek o postawie indyferentnej jedynie afirmuje fakt życia, negując religację. Jest to zatem olbrzymia amputacja dokonana na własnym życiu osobowym. Ta obojętność nie polega na nieposiadaniu problemu Boga ale na nie-zrozumieniu siebie (des-entenderse) i na nie-zatroskaniu się (des-preocuparse) o fundament. To "nie” (des-) to nie brak problemu Boga, tylko pewien pozytywny sposób przywłaszczenia sobie ukazanej przez intelekcję możliwości, jaką stwarza problem Boga. Każdy człowiek rodzi się z tym problemem, bo nie jest to problem społeczny. Natomiast indyferentyzm jest wytworem społecznym. Paradoksalnie indyferentyzm jest jednym ze sposobów afirmowania problemu Boga jako problemu ${ }^{65}$.

Indyferentyzm zasadniczo polega na braku woli fundamentu jako czegoś koniecznego w konstruowaniu Ja. Człowiek zatrzymuje się na poziomie rozważań intelektualnych. Tylko gdy punktem wyjścia jest rzeczywistość w całej swojej prawdzie, czyli uwzględniając religację, możemy mówić o poszukiwaniu fundamentu ${ }^{66}$. Oznacza to, że człowiek będąc obojętnym, nie interesuje się problemem fundamentu. Człowiek w swojej intelekcji rzeczywistości nie dochodzi do różnicy między rzeczywistością-przedmiotem (bezosobowy świat) a rzeczywistością-fundamentem (Bóg). Jest mu to obojętne. Jest to zawieszenie wniosku co do charakteru rzeczywistości. Ma tu miejsce jedynie wola życia ${ }^{67}$. Nieinteresowanie się fundamentem jest pewną pozytywną formą życia. Jest to forma życia bez woli fundamentu, ale niepozbawiona fundamentu ${ }^{68}$.

64 X. Zubiri, El hombre..., op. cit., s. 294-298.

65 Ibidem, s. 126-127.

66 Ibidem, s. 284.

67 Ibidem, s. 290-293.

68 M.D. González, s. 85. 


\section{Agnostycyzm}

Ostatnim omawianym przez Zubiriego szkicem jest agnostycyzm. Pojawia się on, gdy szuka się fundamentu, ale się go nie znajduje. $W$ tym wypadku poszukiwanie pochyla się nad samym sobą. To poszukiwanie dla poszukiwania. Wola poszukiwania staje się tym, co ostateczne w rzeczywistości osobowej. Jest to jednak nie do utrzymania. Agnostyk twierdzi, że nie ma dowodów potwierdzających obecność fundamentu (Boga). To, że fundament nie jest bezpośrednio inteligowany, nie oznacza jego niepoznawalności (in-intelegibilidad). Agnostycyzm nie ignoruje problemu Boga, ale uznaje go za nierozwiązywalny. Nierozwiązywalność problemu Boga jest przyjęta przez agnostycyzm jako coś konstytutywnie nierozwiązywalnego. U postaw agnostycyzmu leży frustracja, stąd agnostycyzm jest postawą. Frustracja przekształca się w czyste poszukiwanie. Szukanie jest czymś ostatecznym w życiu osobowym. Jest to zarazem uznanie, że człowiek jest na szczycie jako problem. Tymczasem jest to fałsz, gdyż wcześniejsza jest religacja. W konsekwencji, gdyby było tak jak twierdzą agnostycy, człowiek nie tworzyłby własnego Ja w oparciu o rzeczywistość. Frustracja leżąca u podstaw agnostycyzmu ma charakter nie tyle czysto intelektualny, co osobisty. Tymczasem to rzeczywistość jest czymś ostatecznym, a nie frustracja. Agnostycyzm wyrasta $z$ niezauważenia religacji $\mathrm{i}$ to jest powodem jego odrzucenia przez Zubiriego ${ }^{69}$.

Agnostycyzm to ignorancja co do rzeczywistości Boga. Niemniej Zubiri uznaje, że agnostyk, wie, co ignoruje. Jest to negowanie możliwości poznania Boga. Agnostyk tworzy szkic, który nie nawiązuje zupełnie do doświadczenia rzeczywistości, czyli do religacji. Można tu mówić jedynie o woli poszukiwania ${ }^{70}$. Agnostycyzm nie jest odrzuceniem woli prawdy i dlatego nie jest czymś powierzchownym, tylko wynikającym z przemyśleń. Jest procesem poszukiwania radykalnego. Nie brakuje tu woli fundamentu, choć nie ma tu wiary, która angażuje $\mathrm{w}$ relację z osobowym fundamentem - Bogiem ${ }^{71}$.

Wspomniane wyżej trzy postawy to częściowe rysy woli fundamentu: wola szukania (agnostycyzm), wola życia (indyferentyzm), wola bycia (ateizm). W przypadku wiary (teizm) trzeba mówić o jednoczesnej woli szukania Boga, życia w Bogu oraz bycia w Bogu ${ }^{72}$. Ograniczeniem analizowanych wyżej trzech ostatnich postaw jest to, że prowadzą do

69 X. Zubiri, El hombre..., op. cit., s. 127-129.

70 Ibidem, s. 285-288.

71 M.D. González, s. 84.

72 Ibidem, s. 86. 
fundamentu, który tylko stwarza możliwości i pociąga. Nie wspominają jednak o rzeczywistości jako ostatecznym fundamencie ${ }^{73}$.

Dokonując podsumowania tej wybiórczej panoramy trudności związanych z rozumieniem immanencji Boga w świecie, można zauważyć, że trudności te mają różną genezę. W przypadku filozofii Tomasza z Akwinu źródłem problemów jest trud myślenia o Bogu w innych, nowych kategoriach - innych niż stworzenie. Jest to zatem problem koncepcyjny. W przypadku Jana od Krzyża trudności pochodzą stąd, że jesteśmy bardzo mocno związani z antropomorficznym obrazem Boga i ciężko nam zawierzyć tak odmiennemu i nieznanemu Bogu przychodzącemu w cierpieniu. Być może można zakwalifikować tę trudność jako egzystencjalną. $\mathrm{W}$ przypadku Zubiriego trudność wiąże się z odrzuceniem religacji, czyli tworzenia Ja w oparciu o rzeczywistość, a w konsekwencji niedostrzeganie tajemniczości tworzenia Ja ${ }^{74}$. Dodatkowo w problematykę poznania obecności Boga w świecie Zubiri włącza ludzkie osobiste życiowe zaangażowanie. To ono poprzez szacunek, prośbę i szukanie schronienia w fundamencie rzeczywistości sprawdza, czy jest on osobowym Bogiem ${ }^{75}$. W tym wypadku, zauważa Zubiri, ważną rolę ograniczającą zaangażowanie odgrywają czynniki osobiste, kulturowe i historyczne, które w obecnym czasie szczególnie mocno są widoczne. Tym samym Zubiri uzupełnia poprzednie dwa stanowiska, stwarzając miejsce w metodzie odkrywania obecności Boga w świecie dla takich współczesnych czynników, jak tempo życia wraz z jego antymetafizycznościa konsumpcjonizm, sekularyzacja, nadmierna wiara człowieka we własną potęgę. Z drugiej strony, dochodząc do teistycznej konkluzji, Zubiri zaprzęga do swojej metody pełne ufności i czci zaangażowanie w stosunku do szkicowanego fundamentu - Boga, przez co można zaryzykować, że zbliża się do pozycji Jana od Krzyża. Nic też dziwnego, że niektórzy, jak Diego Gracia - wieloletni uczeń Zubiriego - chcieliby widzieć Zubiriego w linii mistyków, a nie czysto racjonalnych myślicieli.

73 A. Pintor-Ramos, Religación y..., op. cit., s. 325-326.

74 X. Zubiri, El hombre..., op. cit., s. 22-23.

75 Ibidem, s. 217-218. 


\section{Streszczenie}

\section{Geneza trudności związanych ze rozumieniem immanencji Boga. Specyfika ujęcia zagadnienia przez Xaviera Zubiriego}

\section{Słowa kluczowe}

immanencja; wszechobecność; wieczność; antropomorfizm; rzeczywistość; ludzkie Ja; religacja; enigma; siła rzeczywistości

Artykuł omawia zagadnienia związane z immanencją Boga. Zostają w nim przedstawione trudności w rozumieniu Boga jako wszechobecnego oraz wiecznego na podstawie doktryny Tomasza z Akwinu. Drugi rodzaj trudności dotyczy obrazu Boga obecnego w cierpieniu na podstawie doktryny Jana od Krzyża. Jan od Krzyża wyjaśnia, dlaczego Bóg jest obecny w człowieku, mimo nieodczuwania Jego obecności przez człowieka. Zubiri natomiast ukazuje, jak Bóg jest obecny w rzeczywistości, umożliwiając tworzenia ludzkiego Ja. Następnie analizuje przyczyny nieodkrywania obecności Boga w ateizmie, indeferntyzmie oraz agnostycyzmie. Powody, dlaczego tak się dzieje to ignorowanie w ludzkim życiu tajemnicy związanej z tworzeniem ludzkiego Ja oraz niechęć do szukania fundamentu rzeczywistości.

\section{Summary}

\section{Why is it so difficult to understand the immanence of God? Specificity of Xavier Zubiri's point of view}

\section{Keywords}

immanence; omnipresence; eternity; anthropomorphism; reality; human; relegation; enigma; power of the real

The article tries to identify different problems related to immanence of God. It describes difficulties connected with omnipresence and eternity of God in the doctrine of Aquinas. The second type of difficulties is based on the doctrine of John of the Cross. The difficulties are related to the picture of God who is present in the suffering. John explains how God is present in a person even though he or she does not feel his presence. Zubiri explains how God is present in the reality allowing to create human I. Zubiri is analyzing why people do not discover divine presence, which leads to atheism, indifferentism and agnosticism. The 
reasons of the absence of God in their attitudes are ignorance of the mystery in human life related to the creation of human I and unwillingness of looking for the base of the reality.

\section{Bibliografia}

Castro G., Noche oscura del alma, w: (red.) E. Pacho, Diccionario de San Juan de la Cruz, Monte Carmelo Burugos 2000, s. 1033-1062.

González M.D., Dios, problema de todos, w: (red.) Seminario Zubiri - Ellacuría, Voluntad de vida. Ensayos filosóficos, Dirección de Cultura UCA / Departamento de Filosofía e Historia UCA Managua 1993, s. 77-91.

Gracia D., El tema de Dios en la filosofia de Zubiri, Estudios Eclesiásticos, vol. 56, 216- 217/1981, s. 61-78.

Gudiel H.C., La fe según Xavier Zubiri. Una aproximación al tema desde la perspectiva del problema teologal del hombre, Editrice Pontificia Universitá Gregoriana Roma 2006.

Hartshorne Ch., The Divine Relativity. A Social Conception of God, Yale University Press New Haven and London 1948.

Jagłowski M., Realizm transcendentalny Xaviera Zubiriego, Wydawnictwo Uniwersytetu Warmińsko-Mazurskiego Olsztyn 2000.

Jan od Krzyża, Noc ciemna, w: Dzieła, tłum. B. Smyrak, Wydawnictwo OO. Karmelitów Bosych Kraków 1986.

Jan od Krzyża, Droga na Górę Karmel, w: Dzieła, tłum. B. Smyrak, Wydawnictwo OO. Karmelitów Bosych Kraków 1986.

Jan od Krzyża, Żywy Płomień Miłości, w: Dzieła, tłum. B. Smyrak, Wydawnictwo OO. Karmelitów Bosych Kraków 1986.

Jan od Krzyża, Pieśń Duchowa, w: Dzieła, tłum. B. Smyrak, Wydawnictwo OO. Karmelitów Bosych Kraków 1986.

Llenín Iglesias F., La realidad divina. El problema de Dios en Xavier Zubiri, Seminario Metropolitano Oviedo 1990.

Pintor-Ramos A., Dios y el problema de la realidad en Zubiri, "Cuadernos de Pensamiento" 1/1987, s. 107-121.

Pintor-Ramos A., Religación y "prueba" de Dios en Zubiri, "Razón y Fe", nov. 1988, s. 319-336.

Thomae Aquinatis, Summa theologiae, La Editorial Catolica, S.A. Matriti MCMLXIII.

Zubiri X., El problema filosófico de la historia de las religiones, Alianza Editorial, Fundación Xavier Zubiri Madrid 2006

Zubiri, X. Naturaleza, Historia, Dios. Madrid: Alianza Editorial, Fundación Xavier Zubiri Madrid 2007.

Zubiri X., Inteligencia y razón, Alianza Editorial, Fundación Xavier Zubiri Madrid 2008.

Zubiri X., El hombre y Dios, Nueva edición, Alianza Editorial, Fundación Xavier Zubiri Madrid 2012. 